Moh. Sholihin Noor

\title{
PROSPEK EKONOMI SYARIAH DI TENGAH PERSAINGAN EKONOMI ASEAN
}

\begin{abstract}
Abstrak
Pembangunan ekonomi ditujukan untuk meningkatkan produktivitas, sehingga mampu meningkatkan kesejahteraan masyarakat. Perbaikan ekonomi diharapkan dapat menetes dan meresap ke semua lapisan masyarakat bawah (trickle down theory) terlebih untuk masyarakat di pedesaan. Dengan meningkatnya kesejahteraan, maka dengan sendirinya akan berangsur dapat menanggulangi kesenjangan sosial.

Pembangunan ekonomi yang tidak memihak pada rakyat tingkat bawah, akan membuat kecemburuan sosial dan berpeluang untuk memperlebar kesenjangan sosial, yang pada gilirannya akan timbul ketimpangan pendapatan. Ketimpangan pendapatan akan berakibat pada kemiskinan. Oleh karena itu berbicara tentang kemiskinan tidak terlepas dari masalah kesenjangan sosial, karena keduanya merupakan aspek yang saling keterkaitan (interdependensi) dari tingkat kebutuhan manusia dalam meningkatkan kesejahteraan. Oleh karenanya pemerintah mengupayakan untuk mengurangi kesenjangan dengan menurunkan angka kemiskinan dan menghapuskan tingkat pengangguran.

Untuk mewujudkan hal di atas perlu didampingi dengan konsep pembangunan ekonomi syariah yang memiliki sifat komprehensif dan berbasis moral spiritual. Karena ekonomi syariah melibatkan segala komponen masyarakat partisipasif, integratif dan akomodatif berdasarkan prinsip-prinsip keadilan dan pemerataan.

Sistem ekonomi Islam memiliki konsekuensi duniawi dan ukhrawi, karena pada saat akad dilakukan berdasarkan hukum Islam. Tidak sedikit orang yang berani melanggar suatu kesepakatan atau perjanjian, bila hukum itu hanya berdasarkan hukum positif, akan tetapi tidak demikian bila dibarengi dengan perjanjian yang melibatkan masalah agama.

Hal ini akan mampu meningkatkan kepercayaan diri yang memiliki kekuatan untuk bangkit menjaga kesinambungan stabilitas ekonomi yang cukup signifikan, yang pada gilirannya akan dapat mewujudkan dan merealisasikan komunitas ekonomi ASEAN (ASEAN Economic Comunity 2015) nanti.

Di samping itu, sistem perekonomian syariah yang notebone mampu meminimalisir angka kemiskinan yakni dapat ditekan seminim mungkin dari beberapa kemajuan dan perkembangan ekonomi, akan menjadi sebuah opportunity dimana Indonesia akan menjadi sebuah kekuatan dalam menghadapi tantangan ekonomi ASEAN 2015 ke depan.
\end{abstract}

Kata Kunci: $A S E A N$, persaingan, ekonomi, syariah. 


\section{Pengertian Perekonomian Rakyat}

Kata dasar dari perekonomian adalah ekonomi. Ilmu Ekonomi berarti Ilmu mengenal asas-asas produksi, distribusi, dan pemakaian barang-barang serta kekayaan seperti keuangan, perindustrian dan pendayagunaan. ${ }^{1}$ M.L. Jhingan dalam bukunya "Ekonomi Pembangunan dan Perencanaan" mendefinisikan perkembangan ekonomi dikaitkan dengan kesejahteraan ekonomi, yakni suatu proses di mana pendapatan nasional nyata per kapita naik dibarengi dengan penurunan kesenjangan pendapatan dan pemenuhan keinginan masyarakat secara keseluruhan. ${ }^{2}$ Definisi yang dilangsir oleh Jhingan di atas mengandung arti bahwa kenaikan kesejahteraan ekonomi tidak bermuara pada keadilan distribusi (Distributive Justice). Oleh karenanya akan melahirkan kesenjangan sosial ekonomi yang menyolok, sehingga yang kaya semakin kaya dan yang miskin semakin miskin.

Adapun Monser Kahf mendefinisikan tentang ilmu ekonomi sebagai kajian tentang prilaku manusia dalam hubungannya dengan pemanfaatan sumber-sumber produktif yang langka untuk memproduksi barang-barang dan jasa-jasa serta mendistribusikannya untuk dikonsumsi. ${ }^{3}$ Definisi ini mengacu pada pemenuhan kebutuhan melalui produktivitas yang dihasilkan oleh sumber daya alam. Oleh karena itu manusia dituntut untuk meningkatkan kualitas sumber daya manusia (SDM) guna menggali isi bumi untuk memenuhi kebutuhan hidup. Hal ini senada dengan sistem perekonomian yang berbasis Islami yakni kajian prilaku masyarakat untuk memenuhi kebutuhan melalui sumber daya yang tersedia.

Rakyat mempunyai arti segenap penduduk atau kebanyakan orang Rakyat Jelata : rakyat biasa, bukan ningrat bukan bangsawan. Rakyat kecil orang yang berstatus ekonomi sangat kurang. ${ }^{4}$

Pengertian di atas dapat disimpulkan bahwa perekonomian rakyat merupakan suatu unit ekonomi yang berskala kecil dan ditekankan pada para pelaku ekonomi yaitu rakyat itu sendiri. Dalam artian kegiatan perekonomian melalui pemberdayaan masyarakat yang berorientasikan kepada peningkatan kesejahteraan sosial bagi masyarakat pedesaan.

Sebelum memberikan definisi ekonomi rakyat penulis membedakan antara "ekonomi kerakyatan" dengan "ekonomi rakyat". Menurut Umar Juoro ekonomi kerakyatan adalah sistem ekonomi yang mencakup konsep, kebijaksanaan, dan strategi pembangunan. Sementara ekonomi rakyat (people economic) adalah pelaku ekonomi yaitu rakyat. Sedangkan perekonomian rakyat (state of peoples economy) merupakan kondisi atau keadaan ekonomi rakyat. ${ }^{5}$ Penulis juga perlu membedakan antara "ekonomi rakyat" dan "perekonomian rakyat". Sri Edi Swasono ${ }^{6}$ dalam tulisannya "Tuduhan Absurd; Perekonomian rakyat dikatakan tidak Konsepsional?", mengartikan bahwa ekonomi rakyat adalah sektor ekonomi yang berisi kegiatankegiatan usaha ekonomi rakyat, sedangkan perekonomian rakyat adalah sistem ekonomi dimana rakyat dan usaha-usaha ekonomi rakyat berperan integral dalam perekonomian nasional. 
Dari perbedaan di atas maka yang harus diberdayakan adalah ekonomi rakyat bukan ekonomi kerakyatan. Timbul pertanyaan bagaimana cara memberdayakan ekonomi rakyat?. Dalam faktor riil ekonomi rakyat masih belum berdaya, ketidak berdayaan pelaku-pelaku ekonomi rakyat karena adanya sistem monopoli, dan sistem monopoli ini dipegang oleh pemerintah melalui perusahaan konglomerat yang membuat ekonomi rakyat terdesak dan kerdil tidak bisa berkembang $^{7}$. Oleh karenanya, cara yang paling mudah untuk memberdayakan ekonomi rakyat adalah menghapuskan sistem monopoli yang diprakarsai oleh pemerintah itu sendiri.

Muslimin Nasution dalam bukunya "Koperasi menjawab Kondisi Ekonomi Nasional" mengatakan bahwa sistem Ekonomi Kerakyatan adalah semua kegiatan ekonomi yang dilaksanakan oleh dan untuk kepentingan rakyat banyak ${ }^{8}$. Dibagian lain beliau menegaskan bahwa memberdayakan usaha kecil sebagai unsur utama ekonomi rakyat melalui pengembangan kelembagaan koperasi ${ }^{9}$. Dalam karangan yang lain, "Pemberdayaan Ekonomi Rakyat dalam Konteks Pembangunan Nasional" beliau mengatakan bahwa pemberdayaan ekonomi rakyat merupakan amanah konstitusi yang sifatnya imperatif-normatif sebagai perwujudan kemakmuran berdasarkan atas azas kebersamaan dan kekeluargaan, serta memberikan dampak kehidupan masyarakat Islam ${ }^{10}$.

Ekonomi kerakyatan adalah kegiatan perekonomian yang melibatkan rakyat atau seluruh lapisan masyarakat agar mereka dapat meningkatkan produktivitas dalam upaya meningkatkan kesejahteraan. Dan jika rakyat atau masyarakat diberikan kesempatan untuk berusaha mengembangkan produktivitas melalui pemberdayaan masyarakat yang berorientasikan pada usaha produktif, maka akan membuka lapangan kerja bagi rakyat. Dengan demikian daya beli mereka akan dapat meningkat dan pada gilirannya mereka dapat meningkatkan kesejahteraan masyarakat sosial khususnya bagi warga pedesaan. Di pedesaan kita mengenal pertanian rakyat, perkebunan rakyat, kopi rakyat, karet rakyat, perikanan rakyat, pasar rakyat, transportasi rakyat, kerajinan rakyat, ketrampilan rakyat, dll. Hal ini menunjukkan bahwa pemberdayaan ekonomi rakyat tidak hanya sekedar simbolis kepemihakan kepada rakyat, melainkan merupakan strategi implementasi dari kegiatan untuk menciptakan lapangan kerja, memperluas kesempatan usaha sehingga mampu menyerap tenaga kerja yang dampaknya dapat menghapuskan angka pengangguran.

Ekonomi kerakyatan pada dasarnya bertumpu pada keterlibatan rakyat dalam kegiatan perekonomian di pedesaan, karena pada umumnya masyarakat pedesaan mengandalkan pada pertanian. Oleh karena itu sasaran prioritas adalah memperbaiki sarana fisik untuk mengakomodir aktivitas perekonomian, seperti perbaikan jalan desa, revitalisasi irigasi, dan perbaikan jembatan. Karena revitalisasi infrastruktur akan membuka isolasi keterbelakangan sosial kemasyarakatan, disamping mempermudah akomodasi dalam rangka menunjang pelaksanaan program ekonomi kerakyatan. 
Untuk mewujudkan sistem ekonomi kerakyatan, maka dilakukan melalui pemberdayaan masyarakat terhadap pengembangan industrialisasi dengan agribisnis dan agroindustri dengan sasaran masyarakat pertanian tradisional di pedesaan. Dalam upaya-upaya pemberdayaan masyarakat setidaknya harus melalui pendekatan masyarakat pedesaan, karena sebagian besar mereka bertempat tinggal di pedesaan dan pada umumnya berprofesi sebagai petani yang mengandalkan sumber penghasilannya dari pertanian. Masyarakat pedesaan yang identik dengan masyarakat pertanian merupakan wadah kegiatan pemberdayaan ekonomi rakyat, sehingga pengembangan potensi lebih perspektif, mandiri, sejahtera di masa depan.

\section{Prinsip-prinsip Ekonomi Syariah}

Dalam Islam terdapat prinsip-prinsip yang mengintegrasikan segenap tatanan kehidupan manusia di dunia, antara lain moral spiritual, sosial, politik dan ekonomi. Hal yang wajar jika manusia sosial selalu mendambakan suatu kehidupan yang perspektif. Untuk itu dalam beriteraksi harus dilandasi dengan tatanan kehidupan yang religius. Islam menempatkan moral sebagai landasan kehidupan beraktivitas dalam perekonomian. Dalam artian bahwa sistem ekonomi Islam memiliki nilai-nilai religius yang mengantarkan pada pelaku ekonomi untuk berinteraksi guna mencapai kesejahteraan sosial.

Islam menghendaki agar ummatnya mempunyai kehidupan yang sejahtera dan kemakmuran ummat. Oleh karenanya Allah menciptakan manusia sekaligus melengkapi dengan sumber daya alam. (QS. Al-Baqarah [2] : 29), (QS. Hud [11] : 61), (QS. al-A'raf [7] : 10), untuk dijadikan sarana usaha dalam menciptakan kesejahteraan dan kemakmuran.

Kesejahteaan dan kemakmuran akan bisa dicapai jika manusia berusaha dengan kerja keras secara proposional untuk mencukupi kebutuhan hidup. Disini nilai-nilai Islam dalam perekonomian telah meletakkan posisi kerja sebagi aktivitas produktif yang diperintahkan oleh Allah, maka dari itu bekerja dalam memenuhi kebutuhan harus berlandaskan al-Qur'an dan as-Sunnah.

Berdasarkan uraian di atas, penulis akan membahas lebih rinci tentang sistem ekonomi Islam.

Ekonomi Islam menurut Prof. M. Abdul Manan dalam bukunya "Teori dan Praktek Ekonomi Islam" bahwa sistem ekonomi Islam merupakan ilmu pengetahuan sosial yang mempelajari masalah-masalah ekonomi rakyat yang diilhami oleh nilainilai Islam. ${ }^{11}$ Menurut M. Umar Chapra ekonomi "Islamic economics was defined as that branch of knowledge which helps realize human well being through an allocation and distribution of scarce resources that is in confirmity with Islamic teaching" ${ }^{\prime 2}$.

Ekonomi Islam yang didefinisikan di atas adalah menitik-beratkan pada upaya realisasi kebahagiaan manusia melalui proses alokasi dan distribusi sumber daya yang terbatas yang mengacu pada ajaran Islam. 
Sedangkan menurut Ahmad Kursyid bahwa Ilmu Ekonomi Islam adalah sebuah usaha sistematis untuk memahami masalah masalah ekonomi dan tingkah laku manusia secara relasional dalam perspektif Islam ${ }^{13}$.

Definisi ekonomi Islam menurut pemikiran Rodinson M, 1974 yang ditulis oleh Jomo K. S. berpendapat bahwa: The economic doctrine of Islam is to be found in both the Qur'an and the Sunnah ${ }^{14}$. Definisi ini senada dengan Timur Kuran yang mendefinisikan bahwa "The Islamic Economists the individual is guided by a set of behavioural norms derived from the Quran and the Sunna". ${ }^{15}$

Yusuf Qardhawi dalam bukunya "Daurul qiyam wal Akhlaq fil Iqtishâdil Islami", berpendapat bahwa ekonomi Islam merupakan sekumpulan dasar-dasar umum ekonomi yang berlandaskan kepada al-Qur'an dan as-Sunnah. ${ }^{16}$

Pendapat Yusuf Qardhawi ini sepaham dengan pendapat sebelumnya yang lebih menitik beratkan pada tatanan hukum Islam yang bersumber pada al-Qur'an dan al-Hadits dalam setiap kegiatan perekonomian, karena dimungkinkan adanya peluang ketidak jujuran dalam kegiatan ekonomi.

Demikian juga Ibrahim Lubis mendefinisikan ekonomi Islam dalam bukunya "Ekonomi Islam suatu pengantar" bahwa ekonomi Islam merupakan sekumpulan dasar-dasar umum ekonomi yang disimpulkan dari al-Qur'an dan asSunnah. ${ }^{17}$

Dari sederet definisi yang dikemukakan oleh para pakar ekonomi Islam di atas hanya berbeda redaksional, sedangkan esensi yang terkandung didalamnya adalah sama yaitu kegiatan perekonomian yang melibatkan tata kehidupan masyarakat untuk memenuhi kebutuhan hidup yang sesuai dengan dasar-dasar dan aturan-aturan Islam yang terdapat dalam al-Qur'an dan as-Sunnah.

Lain lagi dengan Murasa Sarkaniputra ${ }^{18}$ yang mendefinisikannya lebih memfokuskan melalui pendekatan terhadap Sang Pencipta, seperti yang didefinisikan dalam bukunya "Adil dan Ihsan dalam Perspektif Ekonomi Islam" Ekonomi Islam (Islamic Economy) adalah ilmu yang mempelajari tata kehidupan kemasyarakatan untuk memenuhi kebutuhan hidupnya dalam mencapai ridha Allah.

Definisi di atas ada tiga arti yang sangat mendasar; Pertama adalah prilaku manusia dalam tatanan kehidupan berinteraksi. Kedua, pemenuhan kebutuhan hidup. Dan Ketiga adalah nilai-nilai dasar atau aturan-aturan Islam. Ketiga unsur tersebut merupakan urutan strategis dalam mengemban tujuan hidup di dunia sebagai langkah menuju kebahagiaan di akherat.

Pada dasarnya Islam telah meletakkan konsep Ekonomi Islam sejak lahirnya Islam. Seperti Rasulullah saw. mengajarkan ekonomi Islam melalui ajaran Islam, sehingga lahirlah tokoh-tokoh pemikir ekonomi yang meletakkan ajaran ekonomi Islam secara aplikatif maupun filosofis, seperti Al-Farabi (870-950 M), Ibnu Sina (980-1037M), Imam Ghozali (1058-1111M), Ibnu Khaldun (1332-1406 M), Abu Yusuf Al Maqrizi (731-798 M), dan lain-lain. Jika dilihat sederetan para pemikir Ekonomi Islam ini, maka kelahiran ekonomi Islam jauh lebih awal dibandingkan dengan lahirnya pemikiran ekonomi konvensional. Mereka ini adalah pemikir- 
pemikir ekonomi Islam kontemporer yang telah banyak berkiprah tentang kajian terhadap pemikiran ekonomi Islam, mereka menyumbangkan pemikirannya untuk membuka cakrawala konseptual. Implementasinya dalam mengaplikasikan ekonomi Islam guna meningkatkan kesejahteraan masyarakat. Dari sini penulis meyakini bahwa kelahiran ekonomi Islam pada dasarnya jauh lebih awal dibandingkan dengan lahirnya ekonomi konvensional, seperti Ibnu Khaldun adalah pelopor perdagangan dibanding dengan Adam Smith, Recardo dll.

Sistem ekonomi kapitalis lebih mengedepankan kebebasan individu, sementara sistem sosialis menganut pada kolektivisme. Sistem ini pemerintah sangat dominan dalam mengatur kehidupan berekonomi. (Goverment Planed Economy), karena semua aktivitas, perencanaan, pelaksanaan, dan pengawasan kegiatan ekonomi dilakukan oleh pemerintah pusat.

Muslimin Nasution menguraikan bahwa Ekonomi Kapitalis dan Ekonomi Sosialis dalam hal-hal tertentu memerlukan campur tangan dan penguasaan aktif yang besar dari pemerintah pada cabang-cabang produksi yang menguasai hajat hidup orang banyak untuk dimanfaatkan bagi sebesar-besarnya kemakmuran rakyat ${ }^{19}$.

Pada dasarnya seseorang memiliki kebebasan untuk berinisiatif, berkreasi dan berusaha untuk memenuhi kebutuhan hidup, akan tetapi Pemerintah ikut campur tangan dalam memenuhi kebutuhan individu sebatas tidak merugikan kepentingan umum.

Sosial kemasyarakatan tidak boleh mengedepankan kepentingan mereka, sementara kepentingan individual dikorbankan tidak diperdulikan eksistensi kebutuhan ekonominya. Islam justru menjunjung tinggi asas pemerataan. Oleh sebab itu ekonomi Islam menekankan pada distribusi yang adil untuk mencapai kesejahteraan sosial. Ketidak seimbangan distribusi kekayaan akan menimbulkan ketidak adilan pendapatan yang berakibat konflik sosial.maunpun individu.

Islam berusaha menghubungkan aspek perekonomian dengan kerohanian dalam kehidupan manusia. Islam memberikan landasan ekonomi berbasis moral spiritual. Oleh karenanya setiap aktivitas perekonomian harus mengacu pada penerapan prinsip-prinsip moral spiritual, sehingga etika ekonomi mempunyai keseimbangan untuk memenuh kebutuhan individu maupun kepentingan sosial.

Kekurangan salah satunya akan menimbulkan kepincangan pada aspek lainnya. Maka dalam sistem Islam, meskipun manusia sibuk mengejar kebutuhan materi, namun tidak akan mengabaikan kehadiran Tuhannya, karena Allah selalu mengawasi dan bersama kita. (QS. Al-Hadîd [57] : 4), dan (QS. Al-Fajr [89] : 14). Disini Allah memerintahkan umatnya untuk memelihara keselarasan dan keseimbangan hidup. Islam menjadikan kesejahteraan ekonomi prasyarat untuk meningkatkan moral dan kualitas manusia. Oleh karenanya Ekonomi Islam yang akan menempati posisi perspektif untuk meningkatkan kesejahteraan masyarakat. Itulah sebabnya Allah mengingatkan bahwa setiap kegiatan berniaga harus selalu mengingat kepada-Nya. (An-Nur[24] : 37) 
Sistem ekonomi Islam yang dengan mengharap ridha Allah akan berangsurangsur menempati posisi perspektif untuk dapat meningkatkan kesejahteraan, dan pada akhirnya dapat menanggulangi kemiskinan dan keterbelakangan masyarakat pedesaan. Islam mengajarkan kepada pemeluknya dalam memenuhi kebutuhan pokok agar tidak berlebihan (israf), karena Allah tidak menghendaki orang-orang yang berlebihan. Sebagaimana firman-Nya.

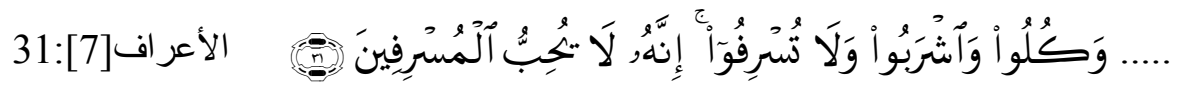

Artinya : ......makan dan minumlah, dan janganlah berlebih-lebihan. Sesungguhnya Allah tidak menyukai orang-orang yang berlebih-lebihan. Al-A'râf[7]:31

Atas dasar uraian di atas dalam konteks keimanan dan ketaqwaan yang mendasari ekonomi Islam, maka seluruh upaya pemenuhan kebutuhan pokok (basic need) untuk menanggulangi kemiskinan, seluruh amal perbuatan dan tingkah laku manusia (behaviours), harus bernafaskan al-Qur'an dan as-Sunnah yang pada akhirnya akan bermuara kepada ridho Allah.

\section{Konsep Islam dalam kegiatan perekonomian}

Islam sebagai ajaran universal bersifat integratif dan komprehensif yang mengajarkan semua aspek kehidupan masyarakat, termasuk didalamnya kegiatan perekonomian untuk menopang kehidupan sehari-hari. Dalam interaksi berbisnis untuk memenuhi kebutuhan, Islam mengatur sistem transaksi berbasis keuntungan yang didasari dengan moral dan etika Islam ke dalam dunia usaha. Etika Islam menjunjung tinggi semangat kejujuran untuk mewujudkan keadilan sosial. Karenanya pelaku bisnis akan menempa diri untuk meningkatkan kinerja guna meraih kesejahteraan.

\section{i. Kewajiban bekerja dan berusaha}

Dalam ajaran Islam perilaku individu dan masyarakat digiring kearah bagaimana pemenuhan kebutuhan mereka dilaksanakan dan bagaimana menggunakan sumber daya yang ada, dan ini merupakan subyek yang dipelajari dalam ekonomi Islam. Oleh karena itu, implikasi ekonomi yang dapat ditarik dari ajaran Islam menjadi berbeda dengan ekonomi konvensional. Islam mengajarkan manusia agar berusaha semaksimal mungkin dengan menyusun langkah strategi agar tujuan mewujudkan kesejahteraan ummat benar-benar tercapai. Dalam hal ini Allah memerintahkan ummat manusia untuk berusaha melalui firman-Nya

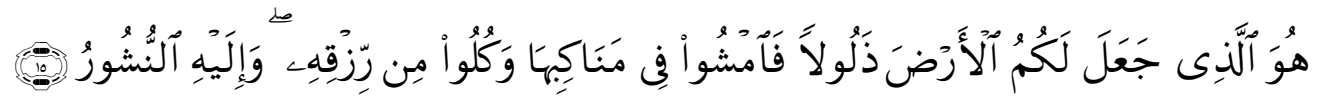

الملك : 15

Artinya : Dialah yang menjadikan bumi ini mudah bagimu, maka berjalanlah disegala penjuru dan makanlah sebagian rizkinya. Dan hanya kepada-Nya 


\section{kamu kembali setelah dibangkitkan al- Mulk : 15

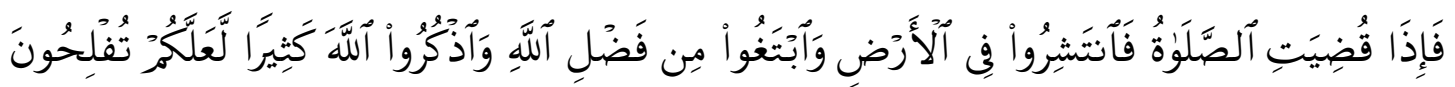 الجمعة : 20 (10}

Artinya : Apabila telah ditunaikan sembahyang, maka bertebaranlah kamu dimuka bumi dan carilah karunia Allah dan Ingatlah Allah banyak-banyak supaya kamu beruntung.

Jumu'ah:10

Untuk itu Islam mengajarkan pemeluknya agar memakmurkan bumi yang telah disediakan oleh Allah, seperti dalam firman-Nya:

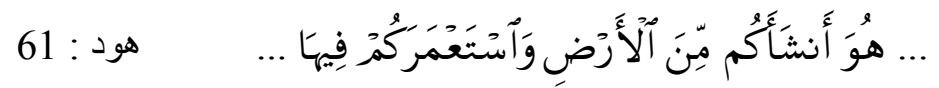

Artinya : ....Dia telah menciptakan kamu dari bumi (tanah) dan menjadikan kamu pemakmurnya,... $\quad$ (QS. Hud: 61)

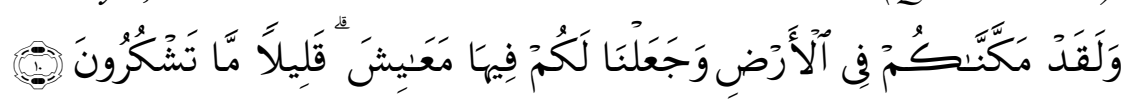

Artinya : "Sesungguhnya Kami telah menempatkan kamu sekalian di muka bumi dan Kami adakan bagimu di muka bumi itu (sumber) penghidupan. Amat sedikitlah kamu bersyukur." (al-A'râf: 10)

Dari beberapa ayat di atas, memberikan pelajaran bahwa bekerja dan berusaha merupakan suatu kewajiban bagi setiap muslim yang tidak kenal henti, sebab ia dituntut untuk selalu produktif di sepanjang hidupnya.

\section{ii. Mengelola isi bumi berbasis moral}

Manusia adalah khalifah Allah atau wakil-Nya di muka bumi (al Baqarah : 30; al An'ân : 165; Fâtir : 39; Shâd; 28; dan al-Hadîd : 7). Ia dibekali dengan semua karakteristik mental dan spiritual serta material untuk mengelola isi bumi meraih kehidupan dan mengemban misinya sebagai wakil Allah. Itulah sebabnya sebagai khalifah fi al-ardh dituntut untuk dapat memenuhi kebutuhan dengan eksplotasi sumberdaya alam dengan berbasis moral, sesuai dengan sabda Rasulullah : "Carilah dunia (harta), seolah-olah kamu hidup seribu tahun lagi".

Dalam hadits Rasul,

$$
\text { اعمل لانياك كأنك تعيش أبدا واعمل لآخرتك كأنك تموت غدا. }
$$

Artinya : Carilah untuk duniamu seolah-olah engkau hidup selama-lamanya, dan carilah engkau buat akhiratmu, seolah-olah engkau akan mati besok. HR. Ibn Asakir 
Jika seorang muslim komitmen dengan ajaran Islam dan menjalankan dengan saksama, maka pengangguran setidaknya akan mengalami penurunan bahkan boleh jadi berangsur-angsur hilang ditelan kesibukan, karena manusia berkeinginan untuk meraih kehidupan yang sejahtera sesuai dengan anjuran Islam itu sendiri.

\section{iii. System bunga mengandung riba}

Ekonomi Islam tidak mengenal system bunga berbunga yang mengandung riba "Adl'âfan-mudlâ'afan" karena riba merupakan praktek yang mengandung penganiayaan dan penindasan terhadap orang-orang yang membutuhkan yang seharusnya mendapat uluran tangan ${ }^{20}$. Riba merupakan kegiatan memakan harta orang lain tanpa jerih payah dan kemungkinan mendapatkan resiko, mendapatkan harta bukan sebagai imbalan kerja atau jasa, menjilat orang-orang kaya dengan mengorbankan kaum miskin, dan mengabaikan aspek perikemanusiaan demi penghasilan materi. ${ }^{21}$ Syafi'i Antonio menjelaskan tentang bunga bahwa bunga merupakan sumber bahaya dan kejahatan, bunga akan menyengsarakan dan menghancurkan masyarakat melalui pengaruhnya terhadap karakter manusia. ${ }^{22}$

Dari berbagai pendapat tentang riba di atas, dapat disimpulkan bahwa riba di dalamnya terdapat unsur penindasan (kedzaliman) terhadap orang-orang yang membutuhkan bantuan. Dalam riba dikenal istilah adl'âfan mudlâ'afan, dan dalam bunga dikenal istilah bunga berbunga yang kesemuanya mengandung unsur penindasan/penyiksaan. Oleh karenanya Allah melarang berbagai bentuk transaksi yang di dalamnya terdapat unsur riba atau bunga, karena akumulasi bunga berbunga semakin hari semakin menjerat itu terdapat unsur mendzalimi terhadap orang-orang yang meminjam untuk memenuhi kebutuhan sehari-hari, baik kebutuhan konsumtif maupun usaha mikro produktif.

Pembayaran bunga yang menyengsarakan para pengguna dana itu, Allah telah memberikan solusi alternatif melalui sistem bank syariah dengan menggunakan sistem bagi hasil yang saling menguntungkan kedua belah pihak dan tidak mengandung riba.

Transaksi mu'amalah syariah seperti mudhârabah, murâbahah, musyârakah dalam tatanan bagi hasil tidak mengandung unsur "tidak mendzalimi dan tidak boleh

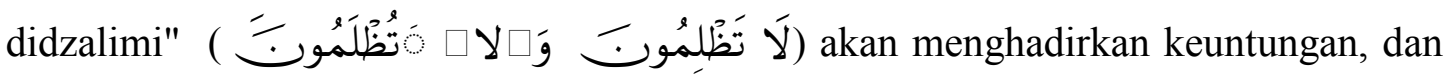
boleh jadi keuntungan akan lebih besar tergantung dengan kenerja seseorang dalam meningkatkan produktivitas.

Uraian di atas menunjukkan bahwa ekonomi Islam menghapuskan sistem bunga dan memberikan alternatif melalui pendekatan sistem bagi hasil dalam bertransaksi tidak terdapat suatu fixed and certain return sebagaimana bunga, dimana kedua belah pihak saling mendapatkan keuntungan dan akan menanggung resiko bersama-sama serta terhindar dari unsur merugikan dan dirugikan 


\section{Peran Negara Terhadap Perekonomian}

Peran serta Negara dalam persoalan ekonomi sangat dibutuhkan, namun kebutuhan seperti apakah yang diperlukan? Hal ini akan menjadi menarik karena pasti ada perbedaan perspektif antara ketiga aliran ekonomi yaitu Kapitalis, Sosialis dan Islam. Sebelum menjelaskan posisi negara (pemerintah) dalam kaitannya dengan ekonomi, disini penulis akan paparkan kepemimpinan yang diinginkan oleh Islam, karena peran efektif Negara sebagai mitra, katalisator dan fasilitator sangat dibutuhkan untuk misi Islam.

Nabi Muhammad pernah bersabda : "Tuhan lebih banyak mengendalikan melalui penguasa dari pada apa yang dikendalikan melalui al-Qur'an"23 al-Qur'an hanya menyediakan norma-norma, sementara penguasa menjadi fasilitator tegaknya wahyu dengan kepemimpinan dalam Islam. Ibnu Taimiyyah juga menganggap bahwa Islam dan Negara mempunyai hubungan yang tak dapat dipisahkan, satu pihak tidak dapat menjalankan perannya dengan baik tanpa ada dukungan dari pihak lainnya. Proses implementasi syari'ah tidak akan mungkin tanpa adanya negara memainkan peran penting. ${ }^{24}$ Akan tetapi Ibnu Khaldun secara jelas menyatakan ketidak setujuannya atas peran Negara secara langsung didalam ekonomi. Negara sangat jarang memainkan peran ekonomi secara dominan dalam sejarah.

Dibeberapa Negara seperti Amerika Serikat (blok barat) menerapkan konsep laissez-faire. Dimana perjalanan ekonomi diberikan kebebasan kepada pelaku ekonomi dengan seluas-luasnya. Implementasinya adalah adanya persaingan bebas antara individu-individu sebagai pelaku ekonomi. Konsekwensi logis yang harus diterima adalah individu-individu yang mempunyai modal semakin kuat, sementara individu individu yang tidak mempunyai modal semakin tertindas. Jadi, instrument ekonominya adalah pasar, Sementara di negara-negara yang menganut faham sosialis menerapkan sistem ekonomi yang kontradiktif dengan kapitalis. Negara mempunyai hak mengatur kepada rakyat khususnya di bidang ekonomi. Rakyat tidak bisa berbuat apa-apa karena semua aktivitas ekonomi berada ditangan penguasa. Wujudnya adalah bahwa kekayaan sumber daya alam dimiliki mutlak oleh Negara.

Didalam Islam tidak dikenal adanya totalitarianisme. Pengakuan hak atas kekayaan pribadi dan penghormatan atas kebebasan individu selalu ditegakkan untuk itu di dalam Islam dikenal adanya hisbah. ${ }^{25}$ Sebagai contoh, pemerintah mengawasi mekanisme pasar agar terwujudnya keadilan dan tataniaga yang adil dalam melakukan interaksi. Tidak ada keberpihakan pemerinyah dalam mekanisme pasar sehingga pasar berjalan dengan normal. Apabila pemerintah melakukan interpensi terhadap harga, maka salah satu (penjual atau pembeli) akan dirugikan. Namun jika pemerintah menurunkan harga di pasar, maka yang dirugikan adalah penjual. Maka dari itu tidak jarang ditemukan adanya pasar gelap yang ada di bawah kontrol pemerintah. Begitu juga sebaliknya, jika pemerintah menaikkan harga barang, maka pembeli merasa dirugikan, dalam menghadapi kondisi seperti ini, kebebasan pemerintah harus selalu berada pada posisi yang netral demi tegaknya "hisbah" tadi. Solusinya yang ditawarkan Islam adalah, pemerintah harus menyuplai kekurangan 
barang agar harga tetap stabil atau memberikan subsidi harga agar masyarakat dapat menjangkaunya.

Dalam hal lain seperti masyarakat yang tinggal di pedesaan baik yang bermata pencaharian sebagai petani maupun nelayan, system ekonomi Islam dimungkinkan dapat dijadikan solusi alternative untuk menanggulangi kemiskinan yang selama ini mengalami kegagalan. Untuk itu penulis mencoba melakukan pendekatan sinergi antara ekonomi Islam dengan program pemberdayaan masyarakat partisipasif.

Ekonomi Syariah atau Ekonomi Islam bersinergi dalam program pemberdayaan masyarakat tani pada dasarnya agama Islam memberikan landasan moral pada masyarakat untuk beraktifitas dalam memenuhi kebutuhan hidup. Oleh karena itu pemerintah baik di tingkat pusat ataupun daerah harus berkolaborasi perencanaan program pemerintah dengan sistem ekonomi Islam dan melibatkan masyarakat pedesaan itu sendiri. Dengan demikian mereka akan bersinergi dalam memenuhi semua kebutuhan pokok dan pada gilirannya mereka akan memiliki kemandirian ekonomi, secara bertahap mereka dapat meningkatkan taraf hidup yang lebih baik.

Dalam perencanaan program pemberdayaan masyarakat pedesaan hendaknya mengedepankan aspek moral, karena melalui landasan moral akan menciptakan keadilan, pemerataan, kepedulian sosial, karena didalamnya terkandung nilai-nilai agama. Oleh sebab itu pemerintah sebagai regulator agar berperan aktif sebagai aktor muamalah dalam mewujutkan perekonomian rakyat yang mampu meminimalisir penyimpangan moral.

Perencanaan program pemerintah harus terintergrasi pada nilai-nilai dasar yang terdapat dalam prinsip-prinsip ekonomi Islam. Melalui prinsip-prinsip ekonomi Islam dapat bersinergi dengan program pemerintah untuk menggali potensi sumberdaya alam, sehingga dapat meningkatkan produktivitas. Dengan demikian sistem ekonomi Islam dapat berjalan dan berkembang dalam masyarakat pedesaan untuk mewujudkan kesejahteraan yang berkeadilan sosial bagi masyarakat. 


\section{Peluang dan Tantangan menuju Masyarakat Ekonomi ASEAN 2015}
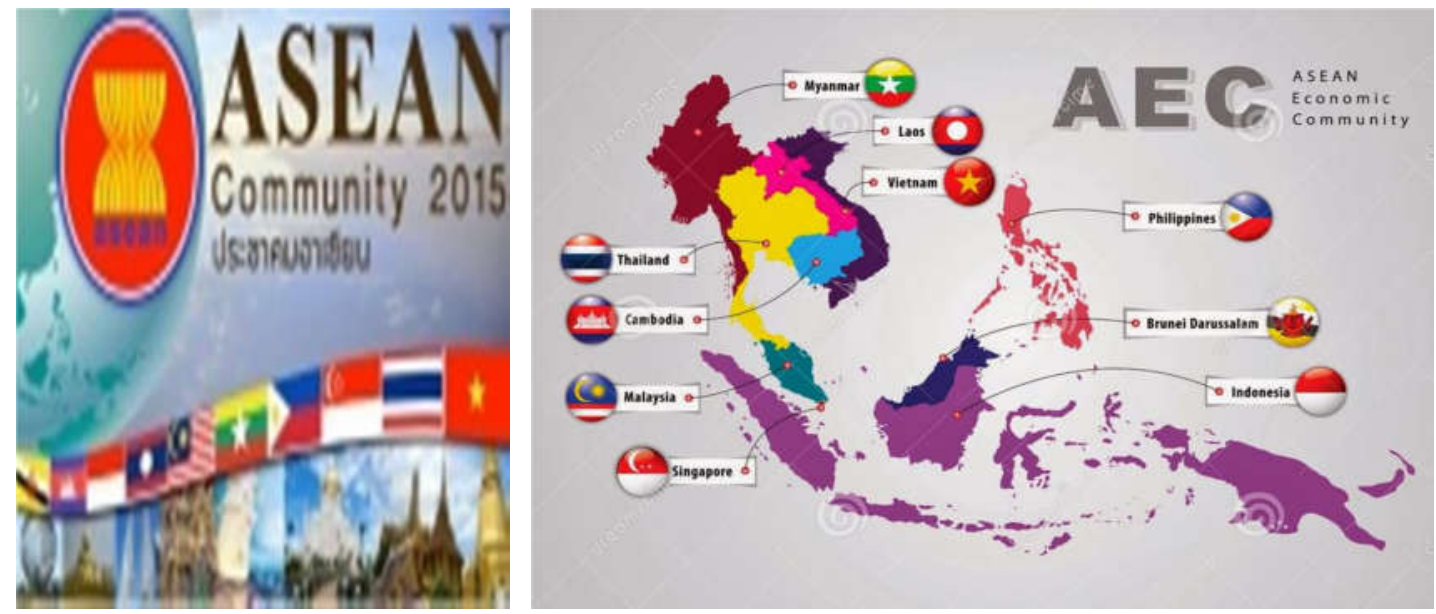

\section{Peranan Tenaga Kerja Indonesia Yang Berdaya Saing}

ASEAN Community atau dalam bidang ekonomi lebih dikenal sebagai ASEAN Economic Community (AEC) merupakan sebuah komunitas yang beranggotakan 10 negara di asia tenggara yang tergabung dalam ASEAN demi terwujudnya ekonomi yang terintegrasi . AEC atau Masyarakat Ekonomi ASEAN (MEA) adalah suatu wadah bagi negara negara di ASEAN untuk mengintegrasikan dalam bidang ekonomi.

ASEAN Community tersebut bertujuan untuk meningkatkan kesejahteraan seluruh anggota ASEAN sehingga mampu menghadapi persaingan pada lingkup regional dan global. ${ }^{26}$ Deklarasi tersebut sebagai respons terhadap care of human security yang mencakup keamanan ekonomi, keamanan pangan, keamanan kesehatan, keamanan lingkungan, keamanan individu, keamanan komunitas, dan keamanan politik.

ASEAN Community ini akan diimplementasikan dan ditargetkan terintegrasi penuh pada tahun 2020, namun dipercepat menjadi tahun 2015. Untuk menjalin keakraban antara negara ASEAN, diperlukan tiga pilar yaitu pilar sosial budaya Socio-Cultural Community, pilar ekonomi Economic Community dan pilar politik kemanan Security Politic Community. Ketiga pilar ini dibentuk dikarenakan tiap tiap negara ASEAN memiliki kesamaan kebudayaan yang dapat merekatkan negara anggota ASEAN.

Negara-negara yang tergabung dalam AEC memberlakukan sistem pasar tunggal single market dan terbuka untuk melakukan perdagangan barang, jasa, investasi, modal dan tenaga kerja. Dengan diberlakukannya AEC tiap - tiap negara akan terintegrasi dalam bidang produksi untuk meningkatkan efisiensi.

Dari realita di atas maka Kerjasama pelaku produksi antar negara akan semakin berkembang untuk menciptakan efisiensi dengan nilai tinggi, dan akan 
meningkatkan nilai kompetitif negara-negara ASEAN dalam rangka meningkatkan produk yang berkualitas tinggi.

Indonesia mempunyai kekuatan ekonomi yang cukup bagus, yakni pertumbuhan ekonomi tertinggi di dunia 4,5\% setelah RRT dan India ${ }^{27}$ ini akan menjadi modal yang penting untuk mempersiapkan masyarakat Indonesia menuju AEC tahun 2015. Oleh sebab itu Indonesia sudah saatnya untuk membekali diri dan mengantisipasi dari pengaruh liberalisasi akan mengarah pada efisiensi pasar.

Dalam menghadapai ASEAN Economic Community ini Indonesia mempunyai Sumber Daya Alam dan Sumber Daya Manusia yang handal dan penduduknya $70 \%$ merupakan usia produktif dan memiliki tenaga kerja 110 juta tenaga kerja ${ }^{28}$. Oleh sebab itu bangsa Indonesia segera berbenah diri untuk menciptakan Sumber Daya Manusia Indonesia yang kompetitif berkualitas global, karena seiring dengan proses peningkatan SDM juga diikuti dengan gerak negara lain untuk berkompetisi. Peluang yang sekaligus merupakan tantangan bagi kalangan professional muda untuk meningkatkan kerja sama, pendekatan bersama dan alih teknologi antar negara anggota ASEAN dengan Organisasi regional dan internasional. Upaya strategi yang harus dilakukan adalah meningkatkan riset bersama dan alih teknologi untuk produk-produk pertanian, pangan dan kahutanan.

Mendorong kerja sama koperasi pertanian ASEAN sebagai sarana untuk memberdayakan dan meningkatkan akses pasar bagi produk-produk pertanian, membagun mekanisme jaringan yang menghubungkan koperasi-koperasi pertanian, dan memenuhi tujuan koperasi pertanian untuk memberikan manfaat bagi para petani. Upaya yang harus dilakukan adalah memperkuat aliansi strategis antar koperasi pertanian ASEAN, membentuk hubungan usaha antar koperasi pertanian potensial, dan meningkatkan investasi dan kemitraan strategis dengan koperasi pertanian ASEAN

Tantangan bangsa Indonesia kedepan adalah mewujudkan perubahan yang berarti bagi kehidupan keseharian masyarakatnya. Semoga seluruh masyarakat Indonesia kita ini bisa membantu untuk mewujudkan kehidupan ekonomi dan sosial yang layak agar kita bisa segera mewujudkan masyarakat ekonomi ASEAN.

Dalam menyongsong pasar tunggal ASEAN ketika arus liberalisasi jasa termasuk jasa profesi baik skillful labor maupun semi-skilled labor akan semakin deras mendekati 2015. Tugas pemerintah dan para pemangku kepentingan yang terkait ialah mempersiapkan sumber daya manusia unggul dan berdaya saing dengan memastikan pembangunan ekonomi linear dengan pembangunan manusia. Kualitas tenaga kerja yang tinggi akan hadir apabila kualitas pembangunan manusia Indonesia berdaya saing unggul. Oleh sebab itu akses terhadap pendidikan, kesehatan, pekerjaan, gizi, dan fasilitas publik lainnya akan menentukan kualitas manusia dan tenaga kerja Indonesia.

Peluang yang sudah terbuka ini mutlak harus segera direspon dan dimanfaatkan, kalau tidak bangsa kita akan tertinggal, karena proses ini juga diikuti oleh gerak negara lain yang terus bergulir. 


\section{Peranan Ekonomi Syariah dalam peluang Ekonomi ASEAN}

Penulis telah berbicara banyak tentang Ekonomi Syariah, Perekonomian Rakyat, dan Konsep Islam dalam kegiatan perekonomian yang kesemuanya adalah upaya pemberdayaan rakyat dan masyarakat pedesaan untuk mencapai kesejahteraan dan kemakmuran masyarakat. Kerja keras secara proposional untuk mencukupi kebutuhan merupakan implementasi nilai-nilai Islam dalam tatanan perekonomian, karena Islam telah meletakkan posisi kerja sebagai aktivitas produktif yang diperintahkan oleh Allah, oleh sebab itu aktivitas perekonomian harus berlandaskan al Qur'an dan as-Sunnah.

Indonesia yang penduduknya mayoritas beragama Islam dan $80 \%$ tinggal dipedesaan $^{29}$, masyarakat pedesaan berpotensi untuk meningkatkan produktivitas. Itulah sebabnya ekonomi syariah akan membawa stabilitas keuangan dalam negeri, karena dasar dari ekonomi syariah adalah menyeimbangkan sector riil dan moneter. Ekonomi syariah juga diyakini dapat mewujudkan pemerataan pembangunan ekonomi. Oleh sebab itu pemerintah hendaknya mendukung keberadaan ekonomi syariah untuk bisa berperan dalam berbenah diri menjelang diberlakukannya masyarakat ekonomi ASEAN 2015.

Mengutip pendapat Menko Perekonomian Chairul Tanjung ${ }^{30}$ menyatakan bahwa"Bagaimanapun sebagai negara muslim terbesar, kita bisa mengambil peran dalam ekonomi syariah. Tantangan terbesar ada pada Malaysia, ekonomi syariah kita kalau mau berperan, kita tidak boleh kalah dari Malaysia, jadi pasar negara Islam di kawasan harus dikontrol oleh kita, itulah tantangan bagaimana menyiasati ekonomi ASEAN yang lebih terbuka,"

Choirul Tanjung dalam pemaparannya menambahkan bahwa ekonomi syariah tidak hanya dihubungkan dengan ekonomi keuangan syariah, melainkan ekonomi syariah sangat luas termasuk kosmetik, fasion dan pariwisata, oleh sebab itu dia optimis Indonesia dapat mengambil peran ekonomi syariah dalam menghadapi masyarakat ekonomi ASEAN.

Optimisme Choirul Tanjung sangatlah beralasan karena dalam ekonomi syariah mempunyai strategi perspektif kedepan dalam menyiasati ekonomi ASEAN, jika peluang ini terabaikan dan tidak siap maka justru produk dari negara lain akan membanjiri pasar Indonesia, seperti banyaknya produk impor yang masuk ke Indonesia.

"MEA 2015 mendatang akan menjadi pasar terbuka dikawasan ASEAN. Hal tersebut akan memberikan peluang dan sekaligus tantangan untuk mengembangkan pasar bagi industri keuangan syariah, sehingga industri keuangan syariah bisa beroperasi lintas negara Asean. Dalam menghadapi MEA 2015, ini pula harus diterapkan kebijakan dan regulasi untuk mendukung industri keuangan syariah Indonesia ${ }^{31}$. " ujar Muchlasin ketika ditemui dalam Dialog Keuangan Syariah di Menara Anugrah, Jakarta, Kamis (19/9/2013). Lebih lanjut ia memberikan langkah langkah strategis untuk merealisasi hal tersebut yakni: 
Pertama : mengembangkan kerangka regulasi yang mendukung pengembangan pasar modal dan Industri Keuangan Non Bank (IKNB) syariah

Kedua : mengembangkan produk pasar modal dan jasa keuangan Non Bank Syariah $^{32}$

Kedua strategi di atas merupakan upaya kesetaraan produk keuangan syariah dengan produk konvensional yang sekaligus upaya meningkatkan Sumber Daya Manusia. di Pasar Modal dan IKNB syariah

\section{Sektor Tenaga Kerja Perlu Perhatian Khusus Jelang MEA 2015}

Jelang Masyarakat Ekonomi ASEAN (MEA) 2015 yang akan diberlakukan tanggal 31 Desember 2015 mendatang, agaknya perekonomian Indonesia tidak hanya menyangkut masalah pekerjaan dan pekerjaan yang layak, akan tetapi juga terletak pada struktur lapangan kerja, tingkat upah, dan produktivitas yang relative rendah. Oleh sebab itu sektor ketenagakerjaan Indonesia perlu mendapatkan perhatian khusus yaitu pembenahan terhadap tenaga kerja Indonesia agar dapat bersaing dengan tenaga kerja asal negara tetangga.

Masalah tenaga kerja Indonesia masih menyisakan persoalan yang mandasar, karena ketenaga kerjaan menyangkut dengan penghidupan yang layak. Oleh karena itu keberadaan sumber daya manusia (SDM) yang berkualitas menjadi tumpuan harapan dalam menghadapi masyarakat ekonomi ASEAN.

Berdasarkan data Kementerian Tenaga Kerja dan Transmigrasi menggambarkan, struktur tenaga kerja Indonesia masih didominasi dengan tenaga kerja berpendidikan rendah. Hal ini dibuktikan dengan Jumlah angkatan kerja per Agustus 2012 sebanyak 118,05 juta, sebanyak 82,10 juta adalah lulusan Sekolah Dasar, 38,57 juta lulusan SMP, 27,65 juta lulusan SMA, 13,54 juta lulusan SMK, 3,87 lulusan Diploma dan 8,17 juta lulusan Sarjana ${ }^{33}$.

Rendahnya tingkat pendidikan pada $72 \%$ tenaga kerja Indonesia mengakibatkan sulitnya bagi kelompok masyarakat itu untuk mendapatkan pekerjaan formal dengan tingkat keterjaminan yang relatif lebih baik. Hanya sebagian kecil (8\%) dari komposisi tenaga kerja Indonesia yang berdaya saing, 3\% di antaranya merupakan profesional dengan tingkat pendidikan minimal sarjana, sedangkan 5\% di antaranya merupakan semi-skilled worker dengan pendidikan diploma dan kejuruan ${ }^{34}$.

Dari beberapa data di atas mengindikasikan bahwa struktur tenaga kerja Indonesia masih didominasi dengan tenaga kerja berpendidikan rendah, oleh karena itu tenaga kerja Indonesiadisinyalir daya saing dan produktivitas masih relative rendah. Potret seperti ini menjadi suatu hambatan dalam menyongsong pasar tunggal ASEAN ketika arus liberalisasi jasa termasuk jasa profesi baik skillful labor maupun semi-skilled labor akan semakin deras mendekati 2015.

Untuk menjadi tenaga kerja yang berkualitas dan kompetitif mutlak diperlukan peningkatan kinerja yang handal dan membuka peluang lapangan kerja 
yang pada gilirannya akan berimplikasi daya saing dunia usaha dan perekonomian nasional.

Langkah langkah strategis yang harus dilakukan untuk mengatasi ketenaga kerjaan adalah :

a. Perluasan kesempatan tenaga kerja

b. Peningkatan pendidikan agar menjadi tenaga kerja terdidik

$>$ Relevansi system pendidikan

$>$ Tenaga kerja disesuaikan dengan kebutuhan dunia usaha

$>$ Optimalisasi penyerapan tenaga kerja

c. Pembangunan sarana infrastruktur dalam negeri

d. Kesiapan Indonesia di bidang jasa

Namun yang terjadi sekarang adalah jumlah pencari kerja lebih besar dari jumlah peluang kerja yang ada, sementara gap antara keterampilan pencari kerja dengan kompetensi yang dibutuhkan oleh pasar kerja tidak memenuhi harapan yang diinginkan. Oleh sebab itu program pemerintah mendatang adalah memperbaharui system pendidikan melalui program link and match antara dunia usaha dan pencari kerja.

\section{Pasar Indonesia Paling Potensial menghadapi Masyarakat Ekonomi ASEAN 2015}

Indonesia mempunyai sumber daya alam yang perspektif yaitu negara agraris yang tanahnya sangat cocok untuk ditanami rempah rempah dan tanaman yang banyak dibutuhkan oleh negara lain. Belum lagi sebagai negara maritim yakni lebih dari 50\% Indonesia adalah perairan yang berproduksi perikanan. Sumber daya alam yang produktivitasnya tinggi seperti ini merupakan sarana untuk memperkuat dalam mengahadapi masyarakat ekonomi ASEAN 2015.

Selain hal di atas Sumber Daya Manusia juga mempunyai peran yang sangat penting untuk mengolah hasil alam. Jika sumber daya manusia ditingkat yang masih rendah hendaknya mengejar peringkat kualitas kompetitif dengan pemerataan pendidikan, karena jika sumber daya manusia tinggi, maka ekonomi kita juga akan baik dan tumbuh.

Bekal lain yang harus diperhatikan dan dilengkapi adalah teknologi informasi (TI), kekuatan yang dimiliki Indonesia adalah industry khususnya pada sektor peralatan listrik dan elektronik. Melalui perkembangan inovasi teknologi mudah dilakukan dalam upaya pengembangan produk.

Dengan bermodalkan ketiga hal di atas Indonesia dipastikan mampu memanfaatkan potensi pasar di ASEAN.

Jika Indonesia mampu mengantisipasi pengaruh liberalisasi akan mengarah pada efisiensi pasar jasa, maka hal tersebut berdampak pada peningkatan konsumen, 
dan produktivitas meningkat, serta persaingan yang lebih sehat di dorong. Oleh karena itu pemerintah hendaknya memberikan perhatian khusus pada para pengusaha agar dapat mengembangkan usahanya sekaligus memperluas pasar produksi barang barang.

Langkah yang akan dilakukan oleh pemerintah ialah mengembangkan pemberdayaan Usaha Kecil Menengah (UKM). UKM memiliki peran dan kontribusi yang besar bagi perekonomian nasional. Menurut data BPS, pada 2009 UKM menyumbang sekitar 53.3\% dari total Pendapatan Domestik Bruto (PDB). Kebanyakan UKM tersebut bergerak di sektor pertanian, perdagangan, industri, dan keuangan $^{35}$. Dalam pengembangan UKM Indonesia yang dominan untuk mengembangkannya adalah kaum wanita Indonesia. Pertumbuhan UKM yang dimiliki perempuan di Indonesia ternyata berada di peringkat ke tiga tertinggi di Asia Pasifik $^{36}$. Hal ini tentunya merupakan suatu kebanggaan tersendiri bagi kaum perempuan, terutama di tengah upaya Pemerintah mendorong kewirausahaan sebagai salah satu sektor penggerak aktivitas ekonomi. Atas dasar itu pemerintah hendaknya memfasilitasi dalam pemberdayaan UKM nasional yang berdaya saing tinggi, inovatif, dinamis dan kreatif yang pada gilirannya mampu memperluas pasar Komunitas Ekonomi ASEAN.

\section{Tantangan dan hambatan menuju ekonomi ASEAN 2015}

Menghadapi masyarakat ekonomi ASEAN 2015 akan berdampak pada perkembangan ekonomi di daerah, dikarenakan adanya mobilitas arus barang, jasa, investasi, modal dan tenaga kerja yang akan terus bergerak. Untuk itu daerah harus memiliki strategi khusus berupa sosialisasi dalam kerangka regulasi, kebijakan, dan program program antara lain;

$>$ Meningkatkan produk unggulan daerah

$>$ Mendorong ekspansi promosi barang dan jasa

Untuk merealisasi hal di atas diperlukan langkah langkah strategis yaitu mendorong investasi di daerah melalui penyederhanaan prosedur, mempersingkat waktu, transparansi proses perizinan usaha dan menciptakan iklim investasi yang kondusif.

Sejak pascakrisis ekonomi yang melanda Indonesia iklim bisnis masih belum kondusif yang menyebabkan lemahnya daya tarik suatu daerah sebagai tujuan bisnis dan investasi, dikarenakan faktor keamanan yang tidak menjamin, penegakan hukum dan kebijakan belum tertata baik (good and clean govermance), dan perizinan yang masih berbelit belit dan memakan biaya yang tinggi, serta infrastruktur yang masih rusak, belum lagi merebaknya issue korupsi yang semakin subur.

Wakil Ketua Umum Kamar Dagang dan Industri Indonesia (Kadin) Provinsi Lampung Yusri Putra Tubarat ${ }^{37}$ mengatakan bahwa ;“Arah kebijakan dalam penyesuaian struktural, harus segera dilakukan pemerintah dengan mengadakan reformasi birokrasi dan undang-undang sebagai regulator dan fasilitator. Apalagi 
tahun 2015 telah berlaku Komunitas Ekonomi ASEAN (KEA) 2015, Indonesia harus optimis menghadapinya,"

Beberapa hambatan di atas perlu mendapatkan ektra perhatian serius bagi Indonesia untuk menata kembali dengan menciptakan iklim usaha yang kondusif dan memberikan dukungan kepada pengusaha, memperbaiki infrastruktur yang baik, dan didukung oleh sumber daya manusia yang profesional, serta menghasilkan produk inovatif yang berdaya saing tinggi di tingkat dunia.

Oleh karena itu Indonesia yakni pemerintah harus bekerja keras dengan pemerintah daerah untuk mampu bersaing menjadi pemain di pasar masyarakat ekonomi ASEAN sekaligus berpeluang untuk berekspansi ke wilayah ASEAN, sebab kalau tidak akan terbuka luas bagi produk luar negeri masuk ke Indonesia.

\section{Kesimpulan}

Perekonomian rakyat pada dasarnya bertumpu pada keterlibatan rakyat dalam kegiatan perekonomian di pedesaan, masyarakat pedesaan yang identik dengan masyarakat pertanian merupakan wadah kegiatan pemberdayaan ekonomi rakyat. Oleh karenanya sasaran prioritas adalah memperbaiki sarana fisik untuk mengakomodir aktivitas perekonomian, karena revitalisasi infrastruktur akan membuka isolasi keterbelakangan sosial kemasyarakatan dan mempermudah akomodasi dalam pelaksanaan program ekonomi kerakyatan.

Ekonomi syariah menjadi solusi efektif untuk bersinergi dalam program pemberdayaan masyarakat pedesaan, karena agama Islam memberikan landasan moral pada masyarakat untuk beraktivitas dalam memenuhi kebutuhan hidup. Oleh karenanya pemerintah baik di tingkat pusat ataupun daerah harus berkolaborasi perencanaan program pemerintah melalui sistem ekonomi Islam dan melibatkan masyarakat pertanian itu sendiri. Dengan demikian mereka akan bersinergi dalam memenuhi semua kebutuhan pokok, dan pada gilirannya mereka akan memiliki kemandirian ekonomi, secara bertahap mereka dapat meningkatkan taraf hidup yang lebih baik.

Ekonomi syariah juga diyakini dapat mewujudkan pemerataan pembangunan ekonomi. Oleh sebab itu pemerintah hendaknya mendukung keberadaan ekonomi syariah untuk bisa berperan dalam berbenah diri menjelang diberlakukannya masyarakat ekonomi ASEAN 2015.

Indonesia yang penduduknya mayoritas beragama Islam dan tinggal di pedesaan, sementara masyarakat pedesaan berpotensi untuk meningkatkan produktivitas, maka selayaknyalah harus bisa mengambil peran dalam mempelopori ekonomi syariah di tengah masyarakat ekonomi ASEAN dan menunjukkan keberhasilanya dalam menyejaterakan masyarakat. Tantangan yang mungkin terjadi adalah Malaysia yang juga ikut ambil bagian untuk berperan dalam bersaing, akan tetapi Indonesia tidak boleh kalah dari Malaysia. 
Semoga seluruh masyarakat Indonesia mampu mewujudkan ekonomi Islam sebagai alternative dalam kehidupan ekonomi dan layak untuk menjadi peran penting dalam persaingan masyarakat ekonomi ASEAN 2015 mendatang.

\section{Catatan Akhir:}

${ }^{1}$ Departemen Pendidikan dan Kebudayaan "Kamus Besar Bahasa Indonesia", Balai Pustaka cet 3 h 220

${ }^{2}$ M. L. Jhingan, “Ekonomi Pembangunan dan Perencanaan”, PT Raja Grafindo Persada, Jakarta, h. 7

${ }^{3}$ Monser Kahf, "Sistem Ekonomi Islam", PT Pustaka Pelajar: Yogyakarta, 1995. h.4

4 Departeman Pendidikan dan Kebudayaan, “Kamus Besar Bahasa Indonesia”, Balai pustaka, h.722

${ }^{5}$ Umar Juoro, "mengembangkan ekonomi rakyat" dalam buku "Paradigma Baru Ekonomi kerakyatan Sistem Syariah” PINBUK Jakarta, h 51

${ }^{6}$ Sri Edi Swasono, "Tuduhan Absurd; Perekonomian rakyat dikatakan tidak Konsepsional?" dalam buku "Paradigma Baru Ekonomi Kerakyatan Sistem Syari'ah", editor Baihaqi Abd. Madjid dkk, Cet 1 Februari 2000. h 12

7 System monopoli justru diciptakan oleh pemerintah dan diberikan pengusaha besar dengan memberikan "bagi hasil”" seperti kasus tataniaga jeruk Kalbar, tataniaga cengkeh Sulut,

8 Muslimin Nasution, "Koperasi menjawab Kondisi Ekonomi Nasional" Penerbit Pusat Informasi Perkoperasian (PIP) dan LPEK, Jakarta 2008, h 146

${ }^{9}$ Muslimin Nasution, "Koperasi menjawab Kondisi Ekonomi Nasional", h 147

Mekanisme sistem ekonomi kerakyatan didasarkan pada asas kekeluargaan yang tertera dalam pasal 33 UUD 45 yakni "Perekonomian harus disusun sebagai usaha bersama berdasar atas asas kekeluargaan" implementasi dari pasal 33 diatas adalah bentuk pengembangan koperasi. Keberadaan koperasi simpan-pinjam dapat membantu perekonomian dikalangan masyarakat menengah kebawah. Sebagai ciri bangsa Indonesia sifat kekeluargaan dan usaha bersama serta tolong-menolong ini tercermin dalam

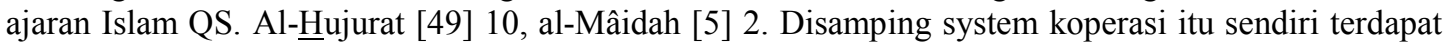
dalam ajaran Islam yang dikenal dengan istilah asy-Syirkah atau Musyarakah.

${ }^{10}$ Lihat Muslimin Nasution, "Pemberdayaan Ekonomi Rakyat dalam Konteks Pembangunan Nasional" dalam Paradigma Baru Ekonomi Kerakyatan Sistem Syariah, h. 75

Amanah konstitusi dalam bentuk TAP MPR Nomor XVI Tahun 1998 tentang Politik Ekonomi dalam rangka Demokrasi Ekonomi.

${ }^{11}$ Prof. Abdul Manan, Teori dan Praktek Ekonomi Islam, Terjemahan Drs. M Nastangin, PT Dana Bakti Prima Yasa: Yogyakarta, 1997, h 19

${ }^{12}$ M. Umar Chapra, "The Future of Economics; an Islamic Perspective”, SEBI Institute, Jakarta 2001 , h 20

${ }^{13}$ Mustafa Edwin Nasution dkk, "Pengetahuan Eksklusif Ekonomi Islam", cet 1, Kencana Jakarta 2007. h 16.

${ }^{14}$ Jomo K. S. Islam and Capitalist Development : A Critique of Rodinson and Weber dalam bukunya "Islamic Economic Alternatives Critical Perspectives and New Directions", Ikraq, Faculty of Economies and Administration Universitay of Malaya Kuala Lumpur, 1993 h. 125

${ }^{15}$ Timur Kuran, The Economic System in Contemporary Islamic Thought dalam Islamic Economic Alternatives Critical Perspectives and New Directions, Ikraq, h. 11

16 Al-Qardhawi, Yusuf, "Daurul Qiyam wal Akhlaq fil Iqtish $\downarrow$ dil Islami”, Penerbit Maktabah Wahbah, Kairo Mesir, cet I tahun 1415 H, h 12

${ }^{17}$ Ibrahim Lubis, "Ekonomi Islam Suatu Pengantar", Jakarta, Kalam Mulia, 1994, h 244

${ }^{18}$ Murasa Sarkaniputra. "Adil dan Ihsan dalam Perspektif Ekonomi Islam" Penerbit Pusat Pengkajian dan Pengembangan Ekonomi Islam. Jakarta 2003, h. 5 
Definisi ini juga terdapat dalam "Pengantar Ekonomi Islam" yang merupakan bahan kuliah pada Fakultas Syari'ah IAIN Syarif Hidayatullah Jakarta.

Sistem Ekonomi Islam diterapkan berdasarkan nilai-nilai yang terkandung dalam al-Qur'an dan alHadits semata-mata mendekatkan diri untuk mengharapkan ridha Allah.

${ }^{19}$ Muslimin Nasution Dr. Ir. APU, "Sistem Demokrasi Ekonom UUD 45" (Pemikiran, Urgensi, Tantangan, Konseptual, Pengertian, dan Tantangan operasionalnya)i", dalam makalah sebagai bahan diskusi pada tanggal 14 Februari 2009 di DPD menegaskan bahwa sebagai bentuk Demokrasi Ekonomi dalam Ekonomi Kapitalis dan Ekonomi Sosialis perlu mendapatkan penanganan Pemerintah secara serius agar hasil produksi dapat dimanfaatkan untuk kemakmuran rakyat dan tidak dinikmati oleh sebagian pihak pengambil keputusan. Lihat Pasal 33UUD 45.

${ }^{20}$ Shihab, M. Quraish “Membumikan Al-Qur'an”,Penerbit Mizan, Cet. XXII, h 266

Beliau menerangkan tentang "Adh'âfan-mudhâ'afan"adalah penambahan dari jumlah kredit karena penundaan pembayaran. Kesimpulan ini diambil dari Al-Thabari yang didukung oleh Muhammad Rasyid Ridha, dan juga oleh Ibn Qayyim. Kesimpulan riba "Adh'âfan-mudhâ'afan" ini bermuara pada penutup surah Al-Baqarah ayat 279, "lâ tadzlim $\boldsymbol{x}_{n}$ wa lâ tudzlam $\boldsymbol{x}_{n}$ " ( kamu tidak menganiaya dan tidak dianiaya). Ayat diatas memperkuat kesimpulan bahwa kelebihan dan pelipat-gandaan merupakan penganiayaan bagi peminjam. H 266

${ }^{21}$ Yusuf Qardhawi, "Peran Nilai Moral Dalam perekonomian Islam" Robbani Press, Jakarta, h 310

${ }^{22}$ Muhammad Syafi'i Antonio, "Bank Syari'ah: Wacana Ulama dan Cendekiawan" Tazkia, 1999, Cet I, h. 109

${ }^{23}$ M. Umer Chapra, "Islam dan Tantangan Ekonomi". Tazkia \& Gema Insani Press; 2000; Jakarta h.75

${ }^{24}$ M. Umer Chapra, "Islam dan Tantangan Ekonomi". Tazkia \& Gema Insani Press; 2000; Jakarta, h. 75-76

${ }^{25}$ Hisbah adalah terjaminnya proses kebaikkan pada saat tingkat kebajikan menurun, dan menengahi kejahatan pada saat tingkat kejahatan meningkat. Lihat Chapra, h.78

${ }^{26}$ Deklarasi ASEAN Community 2008 Salah satu keputusan strategis tersebut yaitu pada KTT ASEAN ke-14 di Thailand Desember 2008, semua negara-negara ASEAN telah meratifikasi Piagam ASEAN (ASEAN Charter) dan sepakat Piagam ASEAN memasuki tahap entry to force.

27 http://www.jurnas.com/haman/10/2011-11-19/189568 diakses tanggal 23 Agustus 2015

${ }^{28}$ Data BPS, tahun 2007, http://isjd.pdii.lipi.go.id/admin/jurnal/162082739. diakses tanggal 23 Agustus 2014

${ }^{29}$ Peter Haqul, Editor "Pembangunan Desa dan Lembaga Swadaya Masyarakat" Penerbit CV

Rajawali Jakarta, 1992 h 11

${ }^{30}$ Choirul Tanjung Menko Perekonomian saat memberikan pemaparan seputar ekonomi Syariah dalam masyarakat ASEAN dengan judul "Ekonomi Syariah Jadi Solusi Siasati Ekonomi ASEAN" pada Rakernas MUI di Hitel Hilton Jakarta 13 Agustus 2014 http://www.islampos.com/menkoperekonomian-ekonomi-syariah-jadi-solusi-siasati-ekonomi-asean-129273. di akses tanggal 24 Agustus 2014

31 Muchlasin “Dialog Keuangan Syariah” Direktur Industri Keuangan Non Bank Syariah Otoritas Jasa Keuangan (OJK) di Menara Anugrah pada hari Kamis tagl 19/9/3013, Muchlasin adalah direktur Industri Keuangan Non Bank (IKNB) Syariah Otorita Jasa Keuangan (OJK)

www.republika.co.id/berita/ekonomi/syariah-ekonomi/14/08/14/nab1w5-ini-kendala-indonesia-dalampengembangan-ekonomi-syariah.

${ }^{32}$ Muchlasin "Dialog Keuangan Syariah"

${ }^{33}$ Data dari Kementerian Tenaga Kerja dan Transmigrasi yang disampaikan oleh Benny Soetrisno, Wakil Ketua Umum Kamar Dagang dan Industri (Kadin) Indonesia Bidang Tenaga Kerja, pada pengarahan jelang masyarakat ekonom ASEAN 2015 di Kantor Kementerian Tenaga Kerja dan Transmigrasi tanggal 12 November 2013 
34 Asean community 2015: Peluang atau tantangan bagi tenaga kerja indonesia http://isjd.pdii.lipi.go.id/admin/jurnal/162082739.pdf

35 Data BPS 2009 diunduh dari http://www.padangtoday.com/?mod=berita\&today=detil\&id=42699, diakses tanggal 23 Agustus 2014

${ }^{36} \mathrm{http}: / /$ www.padangtoday.com/?mod=berita\&today=detil\&id=42699, diakses tanggal 23 Agustus 2014

37 Yusri Putra Tubarat Wakil Ketua Umum Kamar Dagang dan Industri Indonesia (Kadin) Propinsi Lampung, Kegiatan diskusi yang digelar bekerja sama dengan Kementerian Luar Negeri Republik Indonesia, dan Universitas Lampung (Unila) dengan judul menuju komunitas ekonomi ASEAN 2015, dihelat di Ballroom Hotel Sheraton, Bandar Lampung, Selasa (25/2). www.unila.ac.id/kuliah-umummenuju-komunitas-ekonomi-asean-2015/

\section{DAFTAR PUSTAKA}

Abdul Manan, Prof. Teori dan Praktek Ekonomi Islam, Terjemahan Drs. M Nastangin, PT Dana Bakti Prima Yasa: Yogyakarta, 1997.

Abdul Aziz Dahlan dkk. Ensiklopedi Hukum Islam, Jakarta : PT Ichtiar Baru van Hoeve 2000.

Al-Qardhawi, Yusuf, "Daurul Qiyam wal Akhlaq fil Iqtishâdil Islami", Penerbit Maktabah Wahbah, Kairo Mesir, cet I tahun $1415 \mathrm{H}$.

Departemen Pendidikan dan Kebudayaan "Kamus Besar Bahasa Indonesia", Balai Pustaka cet. 3.

Ibrahim Lubis, "Ekonomi Islam Suatu Pengantar", Jakarta, Kalam Mulia, 1994.

Jomo K. S. Islam and Capitalist Development : A Critique of Rodinson and Weber dalam bukunya "Islamic Economic Alternatives Critical Perspectives and New Directions", Ikraq, Faculty of Economies and Administration Universitay of Malaya Kuala Lumpur, 1993.

Monser Kahf, "Sistem Ekonomi Islam", PT Pustaka Pelajar: Yogyakarta, 1995.

M. L. Jhingan, “Ekonomi Pembangunan dan Perencanaan”, PT Raja Grafindo Persada, Jakarta.

Muslimin Nasution Dr. Ir. APU, "Koperasi menjawab Kondisi Ekonomi Nasional" Penerbit Pusat Informasi Perkoperasian (PIP) dan LPEK, Jakarta 2008. 
, "Sistem Demokrasi Ekonom UUD 45" (Pemikiran, Urgensi, Tantangan, Konseptual, Pengertian, dan Tantangan operasionalnya)i", dalam makalah sebagai bahan diskusi pada tanggal 14 Februari 2009 di DPD.

...................., "Pemberdayaan Ekonomi Rakyat dalam Konteks Pembangunan Nasional" dalam Paradigma Baru Ekonomi Kerakyatan Sistem Syariah.

M. Umer Chapra, "Islam dan Tantangan Ekonomi". Tazkia \& Gema Insani Press; 2000; Jakarta.

.................., "The future of Economic : al-Islami Perspectif." Islamic, Fondation.

Mustafa Edwin Nasution dkk, "Pengetahuan Eksklusif Ekonomi Islam", cet 1, Kencana Jakarta 2007.

Murasa Sarkaniputra. "Adil dan Ihsan dalam Perspektif Ekonomi Islam" Penerbit Pusat Pengkajian dan Pengembangan Ekonomi Islam. Jakarta 2003.

Muhammad Syafi'i Antonio, "Bank Syari'ah: Wacana Ulama dan Cendekiawan" Tazkia, Cet I,1999.

Shihab, M. Quraish “Membumikan Al-Qur'an”,Penerbit Mizan, Cet. XXII.

Sri Edi Swasono, "Tuduhan Absurd; Perekonomian rakyat dikatakan tidak Konsepsional?" dalam buku "Paradigma Baru Ekonomi Kerakyatan Sistem Syari'ah", editor Baihaqi Abd. Madjid dkk, Cet 1. 2000.

Syauqi Ahmad Dunya, Dr. "Al Iqtishad al Islami"Makkah, Rabithah Alam Islami, Tahun 1990 diterjemahkan oleh Shodiq Noor, "Sistem Ekonomi Islam" (Jakarta) Fikahati Aneska, Cet 1, 1994.

Timur Kuran, The Economic System in Contemporary Islamic Thought dalam Islamic Economic Alternatives Critical Perspectives and New Directions, Ikraq.

Umar Juoro, "Mengembangkan ekonomi rakyat" dalam buku "Paradigma Baru Ekonomi kerakyatan Sistem Syariah” PINBUK Jakarta.

William A. Mc Eachern, "Economis : a contemporary introduction" diterjemahkan oleh Sigit Triandaru, SE "Ekonomi Makro : Pendekatan Kontemporer" Jakarta, Salemba Empat, Cet 1, 2000. 
Yusuf Qardhawi, "Peran Nilai Moral Dalam perekonomian Islam" Robbani Press, Jakarta.

http://www.jurnas.com/halaman/10/2011-11-19/189568 diakses tanggal 23 Agustus 2015.

http://isjd.pdii.lipi.go.id/admin/jurnal/162082739. diakses tanggal 23 Agustus 2014.

htt://www.unila.ac.id/kuliah-umum-menuju-komunitas-ekonomi-asean-2015/.

http://www.padangtoday.com/?mod=berita\&today=detil\&id=42699, Tgl 23 Agtus 2014.

http://www.republika.co.id/berita/ekonomi/syariah-ekonomi/14/08/14/nab1w5-inikendala-indonesia-dalam-pengembangan-ekonomi-syariah.

http://www.islampos.com/menko-perekonomian-ekonomi-syariah-jadi-solusi-siasatiekonomi-asean-129273.

Moh. Sholihin Noor, akademisi di bidang ekonomi syariah. 